ARTICLE

Received 13 Feb 2016 | Accepted 19 Oct 2016 | Published 29 Nov $2016 \quad$ DOl: 10.1038/ncomms13653 OPEN

\title{
Massive remobilization of permafrost carbon during post-glacial warming
}

T. Tesi ${ }^{1,2,3}$, F. Muschitiello2,4,5,6, R.H. Smittenberg 2,6, M. Jakobsson ${ }^{2,6,7}$, J.E. Vonk ${ }^{8}$, P. Hill7 , A. Andersson ${ }^{1,2}$, N. Kirchner 2,9 , R. Noormets ${ }^{7}$, O. Dudarev ${ }^{10,11}$, I. Semiletov ${ }^{10,11,12} \&$ Ö Gustafsson ${ }^{1,2}$

Recent hypotheses, based on atmospheric records and models, suggest that permafrost carbon (PF-C) accumulated during the last glaciation may have been an important source for the atmospheric $\mathrm{CO}_{2}$ rise during post-glacial warming. However, direct physical indications for such PF-C release have so far been absent. Here we use the Laptev Sea (Arctic Ocean) as an archive to investigate PF-C destabilization during the last glacial-interglacial period. Our results show evidence for massive supply of PF-C from Siberian soils as a result of severe active layer deepening in response to the warming. Thawing of PF-C must also have brought about an enhanced organic matter respiration and, thus, these findings suggest that PF-C may indeed have been an important source of $\mathrm{CO}_{2}$ across the extensive permafrost domain. The results challenge current paradigms on the post-glacial $\mathrm{CO}_{2}$ rise and, at the same time, serve as a harbinger for possible consequences of the present-day warming of PF-C soils.

\footnotetext{
${ }^{1}$ Department of Environmental Science and Analytical Chemistry (ACES), Stockholm University, Svante Arrhenius väg 8, SE-11418 Stockholm, Sweden. ${ }^{2}$ Bolin Centre for Climate Research, Stockholm University, SE-106 91 Stockholm, Sweden. ${ }^{3}$ Institute of Marine Sciences, National Research Council (ISMAR-CNR), Via Piero Gobetti 101, 40129 Bologna, Italy. ${ }^{4}$ Lamont-Doehrty Earth Observatory, Columbia University, 61 Route 9W-PO Box 1000, Palisades, New York 10964-8000, USA. ${ }^{5}$ Uni Research Climate, Nygårdsgaten 112, 5008 Bergen, Norway. ${ }^{6}$ Department of Geological Sciences (IGV), Stockholm University, Svante Arrhenius väg 8, SE-106 91 Stockholm, Sweden. ${ }^{7}$ University Centre in Svalbard (UNIS), P O Box 156, N-9171 Longyearbyen, Svalbard. ${ }^{8}$ Faculty of Earth and Life Sciences, Department of Earth Sciences, VU University Amsterdam, De Boelelaan 1085, 1081 HV Amsterdam, The Netherlands. ${ }^{9}$ Department of Physical Geography (NG), Stockholm University, SE-106 91 Stockholm, Sweden. ${ }^{10}$ Pacific Oceanological Institute FEB RAS, Baltic Street, 690041 Vladivostok, Russia. ${ }^{11}$ Tomsk Polytechnic University, Lenina Prospect, 634050 Tomsk, Russia. ${ }^{12}$ University of Alaska Fairbanks, Koyukuk Drive, Fairbanks, Alaska $99775-$ 7340, USA. Correspondence and requests for materials should be addressed to T.T. (email: tommaso.tesi@ismar.cnr.it).
} 
T he Arctic and sub-Arctic soils hold about twice as much carbon as the pre-industrial carbon inventory in the atmosphere $^{1,2}$. Recent studies have suggested that the permafrost carbon (PF-C) stock in permanently frozen soils during the Last Glacial Maximum (LGM) might even have been substantially higher (by $700-1,000 \mathrm{PgC}$ ) than the contemporary stock in high-latitude soils $(1,300 \mathrm{Pg} \mathrm{C})^{2-4}$. Most of this megapool of PF-C was formed during the Pleistocene through episodes of sediment deposition, which, combined with the low temperatures, resulted in large burial of terrigenous biomass in soils that were not covered by ice sheets ${ }^{3,4}$.

The last glacial-interglacial transition represents a major climatic reorganization during which the Northern Hemisphere became warmer while the atmospheric $\mathrm{CO}_{2}$ rose from $c a .190$ parts per million by volume (p.p.m.v.) to ca. 270 p.p.m.v. ${ }^{5,6}$ (corresponding to $c a .190 \mathrm{PgC})^{2}$. This transition was not gradual, but characterized by abrupt fluctuations in temperature and atmospheric $\mathrm{CO}_{2}$ within the general post-glacial trend. A unique process to explain the $\mathrm{CO}_{2}$ variations has so far not been found. Upwelling of poorly ventilated abyssal water masses is one of the leading hypotheses ${ }^{7,8}$, although the search for a ${ }^{14} \mathrm{C}$-depleted carbon reservoir in the deep ocean remains a matter of current debate $^{9,10}$. Recently, alternative studies based on atmospheric records $^{11}$, terrestrial records ${ }^{3}$ and modelling exercises ${ }^{2,12,13}$ have inferred that destabilization of PF-C reservoirs might have played a key role in regulating atmospheric $\mathrm{CO}_{2}$ levels on glacial-interglacial timescales. However, despite the large amount of carbon held in the northern soils at the LGM, we still do not have direct physical evidence to understand whether this large carbon reservoir remained dormant throughout the climate transition or whether the thermal reactivation of PF-C resulted in large-scale carbon redistribution between earth system compartments.

In this study, we use Laptev Sea sediments (Arctic Ocean) to investigate the putative instability of PF-C in the Lena River catchment (central Siberia) during the last glacial-interglacial period. Initially, we focus on the Younger Dryas-Preboreal transition (YD-PB, ca. 11,650 yBP) during which the Northern Hemisphere experienced an abrupt temperature increase. The YD cooling event was a sudden return to near-glacial conditions during last deglaciation, likely to be triggered by atmosphereocean feedback associated with meltwater fluxes and rapid sea ice expansion combined with a weakened Atlantic Meridional Overturning Circulation ${ }^{14-16}$. Ice cores from Greenland have documented the re-establishment of the post-glacial warming in the $\delta^{18} \mathrm{O}$ record ${ }^{17}$ as a sudden temperature increase. Given the abrupt nature of the YD termination, the YD-PB climate transition represents an ideal benchmark to assess the stability of PF-C during rapid climate warming. Finally, based on a collection of published studies ${ }^{18-21}$, we investigate the PF-C remobilization over a longer deglacial warming period. This study thus presents observation-based evidence of massive PF-C destabilization during past warming events and contributes a new angle to the ongoing debate on mechanisms driving the increase of atmospheric $\mathrm{CO}_{2}$ during the last deglaciation. Our results suggest that thermal reactivation of dormant permafrost might have been an important source of carbon ${ }^{2,12}$.

\section{Results}

Deposition of permafrost in the Laptev Sea during the YD-PB transition. Because of its extensive catchment $\left(2.5 \times 10^{7} \mathrm{~km}^{2}\right.$, the second largest in the Arctic and sub-Arctic regions), the soil carbon supplied by the Lena River to the Arctic Ocean integrates the signal from a vast permafrost domain, which, during the LGM, was largely dominated by the tundra-steppe biome but with the presence of woody taxa as well ${ }^{2-24}$. The piston core investigated in detail here (PC23) was collected in the paleo valley of the Lena River (56 m water depth), now in the central-outer Laptev Sea shelf (Fig. 1 and Supplementary Fig. 1). The downcore chronology was established using Bayesian age-depth modelling based on radiocarbon dating of marine molluscs and large vascular plant fragments (Supplementary Fig. 2 and Supplementary Table 1). The resulting age model indicates that the sedimentary record begins shortly before the termination of the YD and encompasses the entire Holocene.

The late Holocene sediment accumulation rate in the inner shelf of the Laptev Sea is on the order of $41 \pm 13 \mathrm{~cm} \mathrm{ky}^{-1}$ on the basis of ${ }^{14} \mathrm{C}$ dating of fossil calcareous organisms ${ }^{19}$. Similar rates were measured in the Lena prodelta using ${ }^{137} \mathrm{Cs}$ and ${ }^{210} \mathrm{~Pb}$ radioisotopes $^{25}$. Our record shows that during the YD-PB transition the sediment accumulation in the paleo inner shelf was one order of magnitude higher $\left(337 \pm 27 \mathrm{~cm} \mathrm{ky}^{-1}\right)$. Highly laminated sediment strata (Supplementary Fig. 3) -typical of event-driven deposition in river-dominated margins with an absence of bioturbation ${ }^{26}$ - corroborate the rapid emplacement of this deposit. Most importantly, our record indicates that the YD-PB transition in the Laptev Sea was characterized by elevated organic carbon (OC) fluxes $\left(101 \pm 18 \mathrm{gC} \mathrm{m}^{-2} \mathrm{y}^{-1}\right.$; Fig. 2b). These figures are particularly high when compared with the late Holocene flux $(0-7,000 \mathrm{yBP})$ in the Lena prodelta (from 0.04 to $\left.25 \mathrm{gC} \mathrm{m}^{-2} \mathrm{y}^{-1}\right)^{19}$.

By using bulk isotopes and molecular proxies as source diagnostic tools, we have found that the high sedimentation rates and carbon fluxes during the YD-PB warming event reflect a massive deposition of land-derived material. Specifically, the OC deposited during this period is characterized by depleted stable carbon isotopic composition $\left(\delta^{13} \mathrm{C}=c a .-27 \% 0\right)$ typical of terrestrial vegetation (Fig. 2c) ${ }^{27}$. Analysis of fossil biomarkers offers important additional information, because it allows tracing exclusively land-derived carbon pools, circumventing dilutions by $\delta^{13} \mathrm{C}$-depleted river/estuarine phytoplankton, which can exhibit an isotopic signature similar to terrestrial vegetation in the Lena watershed $^{28}$. In this study, we have focused on lignin phenols, a structural biopolymer of higher plants, and cutin-derived products, a waxy biopolymer of plant cuticles ${ }^{29}$. In PC23 fluxes of lignin phenols and cutin-derived products peak at the YD/PB transition consistent with the overall $\delta^{18} \mathrm{O}$ trend (Fig. 2f,g). Furthermore, their carbon-normalized concentrations are remarkably consistent with the average values observed in Siberian permafrost soils ${ }^{30}$ (Supplementary Fig. 4), further confirming the massive OC deposition of terrestrial origin.

According to the age-depth model, the high land-to-ocean carbon fluxes started before the YD termination ( $c a .11,650 \mathrm{yBP})$. After the cold and dry YD onset, the Northern Hemisphere experienced a second phase of the YD relatively more humid and warmer than the initial conditions. In Europe, this was associated with the resumption of North Atlantic overturning ${ }^{31}$. Ice cores from Greenland have recorded the period before the YD termination as a progressive decrease of the Asian dust concentration (Fig. 2d) ${ }^{32}$. This was likely to be the result of northward migration of the intertropical convergence zone and progressively wetter conditions over the Asian deserts, which would justify relatively high OC fluxes already towards the end of the $\mathrm{YD}^{33}$. Climatic reconstruction based on pollen assemblages from the Lena watershed confirms the increase of mean temperature and precipitation towards the end of the $\mathrm{YD}^{24}$, consistent with the high OC fluxes of terrestrial origin observed in our record.

Source of the translocated terrigenous carbon. To quantify the relative input from active layer and deeper/older permafrost sources, we have applied a mixing model based on $\delta^{13} \mathrm{C}, \Delta^{14} \mathrm{C}$ 

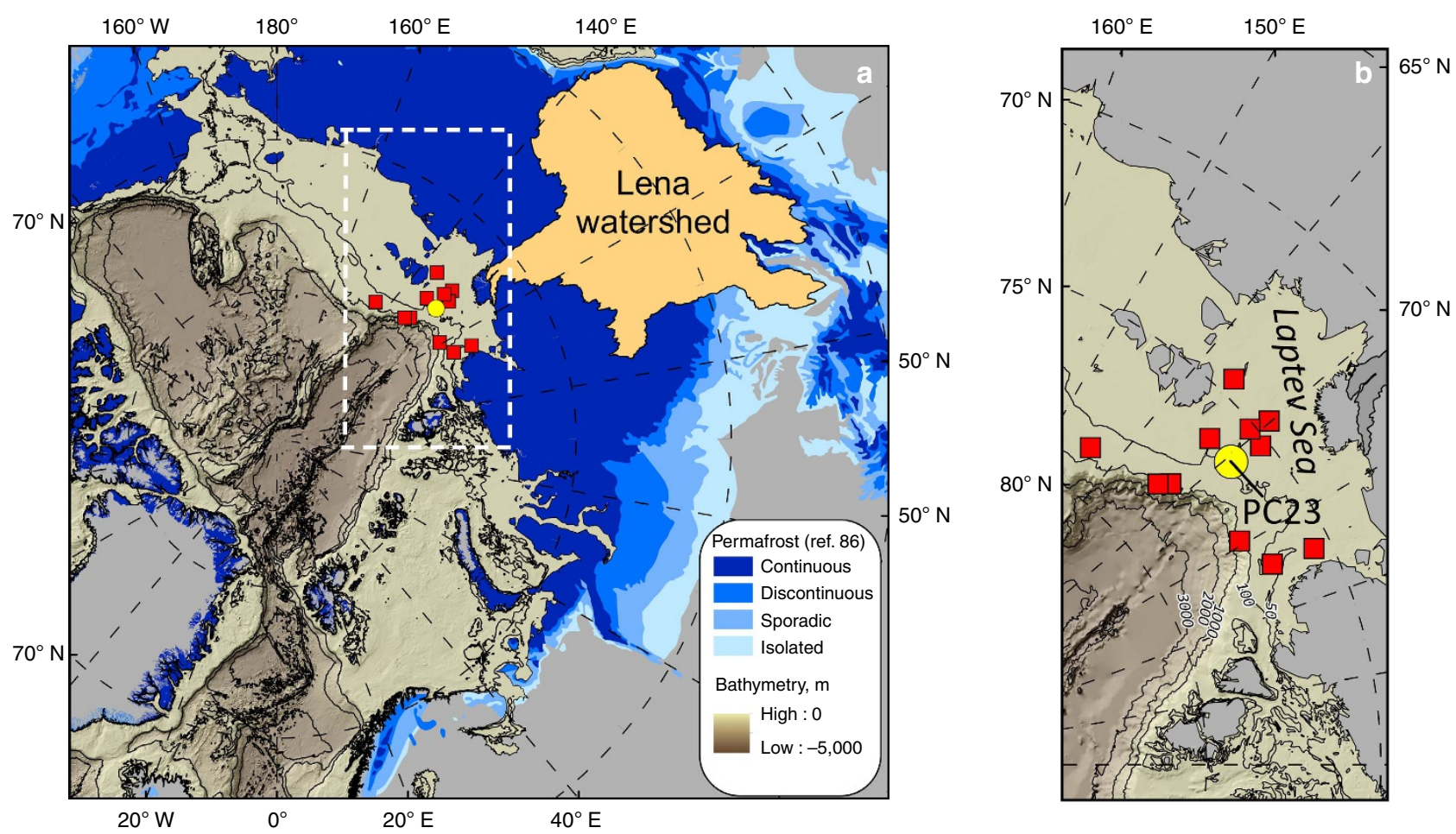

Figure 1 | Location of post-glacial sediment records in the Laptev Sea. (a) Blue shades show the extent of permafrost as continuous, discontinuous, sporadic and isolated ${ }^{86}$. The Lena River watershed is shown as an orange area. The location of PC23 collected during the SWERUS-C3 expedition (2014) in the mid-outer shelf of the Laptev Sea is shown as a yellow filled circle. Filled red squares display the location of other transgressive deposits from published studies that were used for carbon deposition and flux calculations $18,20,82$. (b) Close-up of the sediment records in the Laptev Sea. The region of $\mathbf{b}$ corresponds to the open rectangle shown in $\mathbf{a}$.

and lignin data using a Monte Carlo simulation to account for the natural variability of the end members ${ }^{34}$ (Fig. 3). The statistical mixing model indicates that the material held in the active layer was the major carbon source, accounting for $70-80 \%$ of the carbon supplied during the YD-PB transition (Fig. 4). In our model, ice-rich coastal deposits (that is, Pleistocene Ice Complex Deposit (ICD)), which dominated the lowlands of northern Siberia during the LGM (Figs 3 and 4) and which today still stretch along the Laptev Sea and East Siberian Sea coasts, have been considered part of the deep sources ${ }^{35}$. This view is consistent with a significant fraction of this ${ }^{14} \mathrm{C}$-depleted Pleistocene deposit today entering the margin via coastal erosion and thermal destabilization processes 36,37 . However, despite the abrupt warming and the post-glacial sea level riseca. $4 \mathrm{~m}^{38}$ equivalent to $20-40 \mathrm{~km}$ of coastal flooding during the high sediment accumulation period-source apportionment results undoubtedly indicate that PF-C was supplied from the watershed via surface water runoff rather than thermal collapse or erosion of ice-rich coastal deposits.

Vegetation proxies provide additional important evidence regarding the $\mathrm{OC}$ source ${ }^{39}$ and further confirms the riverderived origin of PF-C. In particular, pollen assemblages from the northern Lena region have shown that trees and shrubs appeared in the northern Siberia (Lena delta region) only after the onset of the Holocene, while during the LGM their abundance progressively increased going southward with some taxa present across their contemporary ranges ${ }^{22,23}$. Lignin fingerprint of ICD samples ${ }^{30,39}$ collected in the Northern Siberia confirms their tundra/steppe-like origin (that is, grass vegetation) in the form of a relatively higher abundance of cinnamyl phenols compared with vanillyl phenols (that is, high $\mathrm{C} / \mathrm{V}$ ratio; Fig. 5). By contrast, the lignin signature of PC23 shows a much greater influence of angiosperm and gymnosperm woody material (low $\mathrm{C} / \mathrm{V}$ ratio), which is indicative of shrub and tree sources, further corroborating the watershed origin. As both ICD and PC23 exhibit the same degradation extent based on lignin fingerprint (Supplementary Fig. 5), we conclude that the compositional differences reflect indeed a distinct origin.

In addition, compound-specific hydrogen isotopes $\left(\delta^{2} \mathrm{H}\right)$ of leaf wax HMW $n$-alkanes (common compounds of plant cuticles) suggest that the watershed-derived material was originally PF-C. Although hydrogen fractionation in plants can occur during evapotranspiration along with plant physiology ${ }^{40}, \delta^{2} \mathrm{H}$ of wax plant lipids largely mirrors the original meteoric signal, which, in first-order approximation, varies as a function of the temperature during moisture formation and condensation ${ }^{41,42}$. Therefore, the depleted $\delta^{2} \mathrm{H}$ signature of HMW $n$-alkanes in the terrestrially dominated section of PC23 indicates that the carbon deposited during the YD-PB transition is indeed terrestrial biomass originally photosynthesized during a cold period most likely to be in a permafrost-dominated environment (Fig. 2e, Supplementary Fig. 6 and Supplementary Table 3). The $\delta^{2} \mathrm{H}$ values measured in PC23 are in fact consistent with a well-studied permafrost loess-paleosol sequence located $c a .1,200 \mathrm{~km}$ upstream of the current Lena river mouth, which has documented the isotopic depletion of leaf wax $n$-alkanes during cold periods throughout the last two glacial cycles ${ }^{3}$.

OC translocation to the Laptev Sea. We have estimated the PF-C buried in the Laptev Sea during the last phase of the deglaciation and early Holocene warm period by compiling all published sediment records available in the region (Fig. 1 and Supplementary Figs 7 and 8), to further explore the deposition of PF-C over a longer timescale characterized by warming 


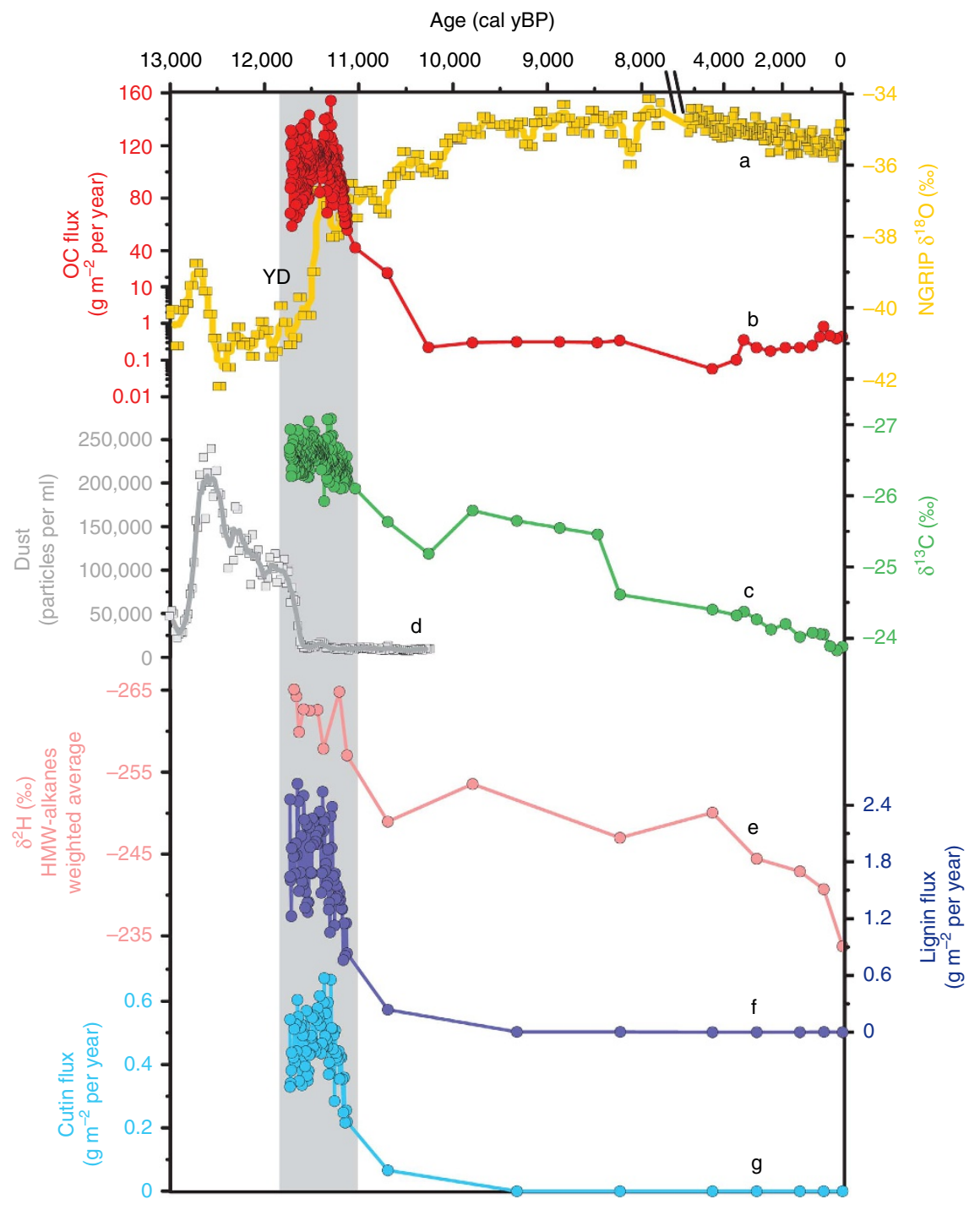

Figure 2 | Sediment record of massive PF-C remobilization during the YD-PB transition and ice core data from Greenland. (a) Oxygen isotopes $\left(\delta^{18} \mathrm{O}\right)$ from Greenland ice cores ${ }^{17}$ (NGRIP; yellow squares and line, five-point weighted average); (b) OC flux (red circles and line and (c) $\delta^{13} \mathrm{C}$ (green circles and line) from the sediment record collected in the Laptev Sea (PC23); (d) dust concentration (particles per ml) from Greenland ice cores ${ }^{32}$ (NGRIP; grey squares and line, five-point weighted average); (e) weighted average hydrogen isotopic composition $\left(\delta^{2} \mathrm{H}\right)$ of high-molecular-weight (HMW) saturated odd $n$-alkanes (C25, C27, C29 and C31; pink circles and line), (f) flux of lignin phenols (dark blue circles and line) and (g) cutin-derived products (light blue circles and line) from PC23 core. The grey vertical region shows the high OC accumulation period. The uncertainty in the Greenland ice core chronology at the YD-PB transition is 99 years $(2 \sigma \text {, not shown })^{87}$.

conditions. The combined data set encompasses 12 sediment cores (Fig. 1), which all demonstrate elevated sediment accumulation rates from the Bølling-Allerød period to the Holocene Climate Optimum ${ }^{18,20,21}$. Accumulation rates are consistent with PC23, which is geographically placed in the middle of the sediment records (Fig. 1). The $\delta^{13} \mathrm{C}$ data, available for three of the additional records, are depleted as PC23, which confirms the deposition of predominantly terrigenous material, regardless of the core location ${ }^{43}$ (Supplementary Fig. 8). The spatial interpolation of these deposits (Supplementary Fig. 9) yields an estimate of $17 \pm 6 \mathrm{PgC}$ (bulk OC) buried in the Laptev Sea during the time period that goes from the mid-Bølling-Allerød to the Holocene Climate Optimum (that is, grey area in Supplementary Fig. 7; from $\mathrm{ca}$. 14 to $7 \mathrm{ky} \mathrm{BP).} \mathrm{As} \mathrm{some} \mathrm{of} \mathrm{these} \mathrm{cores} \mathrm{were}$ collected in paleo-channel settings over the mid-shelf, care should be placed on the absolute value of this upscaling estimate, because these records might not be fully representative of the area.
However, as the greatest thicknesses were observed in the outershelf-with no evident paleo-channel environments-these latest records have comparatively more importance for the upscaling in comparison with shallower deposits (Supplementary Fig. 10).

By using the source apportionment results of PC23 and accounting for post-depositional degradation (Supplementary Methods, Source apportionment calculations ), we estimate an active-layer carbon cumulative flux to the seabed of $31 \pm 9 \mathrm{PgC}$ from the watershed adjacent to the Laptev Sea, which yields an average annual land-to-ocean export of $4.5 \pm 1.4 \mathrm{TgCy}^{-1}$. Comparison with the modern input from the Lena and other minor rivers $\left(0.66 \mathrm{Tg} \mathrm{Cy}^{-1}\right.$; Supplementary Methods, Comparison with the modern river input; Supplementary Fig. 11) reveals that PF-C supplied to the Laptev Sea during the late deglaciation/ early Holocene was particularly elevated and equivalent to at least seven times the modern river input, which further confirms the massive release of PF-C as a result of the post-glacial warming. 


\section{Discussion}

This study provides observation-based evidence of massive PF-C destabilization during the YD-PB transition. Specifically, our data suggest extensive active-layer translocation in the Lena watershed and surrounding catchments adjacent to the Laptev Sea. Collective evidence based on published studies in the region also reveals high land-to-ocean carbon fluxes throughout the last deglaciation ${ }^{18,20,43,44}$.

We infer that the enhanced sediment production in response to the warming probably played first-order control on the greater

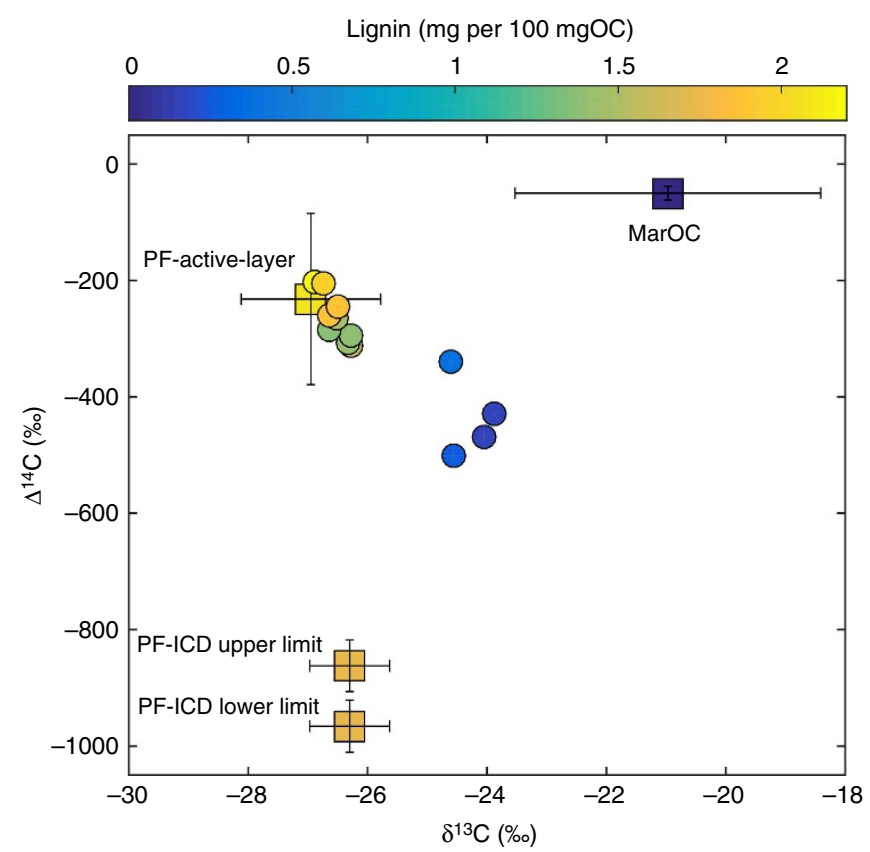

Figure 3 | OC source apportionment in the Laptev Sea sediment record. The figure shows the relative contribution of three distinct $O C$ sources shown as squares: marine OC (MarOC), Permafrost ICD (PF-ICD and PFActive-layer). The source apportionment is based on $\delta^{13} \mathrm{C}, \Delta{ }^{14} \mathrm{C}$ and lignin content (shaded colours). The error bars show the natural uncertainties of each source based on literature data. Further details about the endmember definition and the source of the data are provided in the Supplementary Methods. Circles show the composition of the sedimentary OC in PC23. The radiocarbon signature of the ICD was corrected to account for the ${ }^{14} \mathrm{C}$ decay (see Supplementary Methods) based on the age-depth model. The upper and lower limits of PF-ICD show the range of radiocarbon values obtained with the correction. terrestrial carbon fluxes. Specifically, Siberian lands during cold periods (for example, LGM and YD) are dominated by extensive and continuous permafrost underlying a thin active layer as suggested by paleo-permafrost modelling ${ }^{45}$ (Fig. 6a). Under these

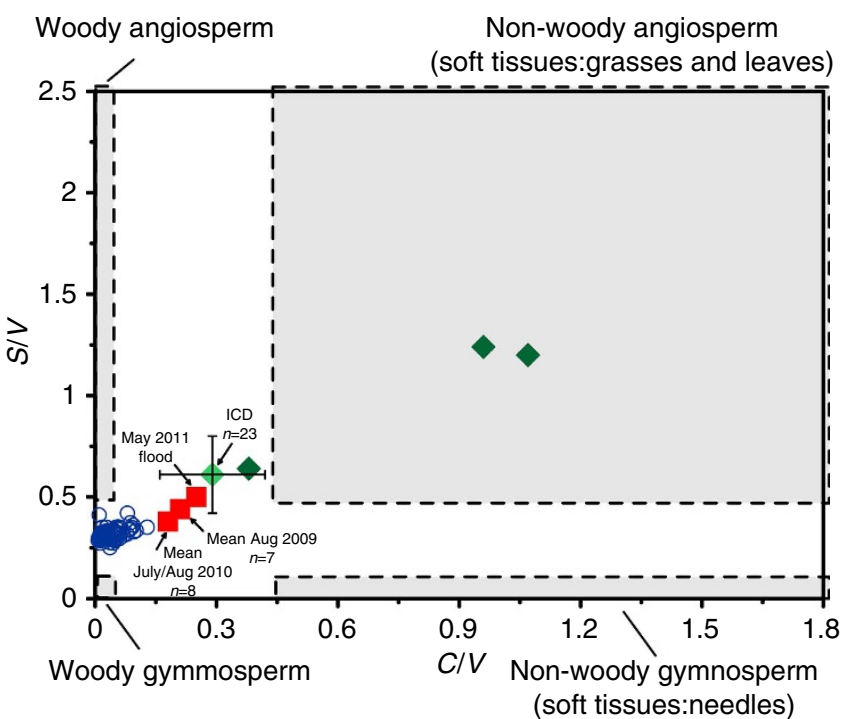

$$
\begin{aligned}
& \text { Ice complex deposit (ref. }{ }^{39} \text { ) } \\
& \text { Ice complex deposit (ref. }{ }^{30} \text { ) } \\
& \text { Modern Lena river POC } \text { (ref. }^{39} \text { ) } \\
& \text { PC23 core (this study) }
\end{aligned}
$$

Figure 5 | Lignin fingerprint of the YD-PB transition in PC23 sediments. Grey boxes show the plant type based on the typical lignin fingerprint range: woody gymnosperm (bottom left), woody angiosperm (top left), soft-tissue gymnosperm (bottom right) and soft-tissue angiosperm (top right). During the Pleistocene, relatively high syringyl phenols to vanillyl phenols ratios $(C / V)$ and high cinnamyl phenols to vanillyl phenols ratios $(S / V)$ indicate an important soft-tissue contribution in ICD samples (green diamonds) likely to be in the form of grass-like material typical of tundra/steppe biome ${ }^{30,39}$ (error bars display the standard deviation of 23 measurements). Lignin fingerprint of PC23 (blue circles) indicates a much larger contribution of angiosperm and gymnosperm woody plants (shrubs and trees) from the watershed. This is consistent with pollen assemblages, which indicate the occurrence of woody plants in northern Siberia soils (Lena delta) only after the onset of the Holocene ${ }^{23}$. As a reference the figure shows the modern Lena input based (red squares) ${ }^{39}$ (error bars are not available for the averaged values).

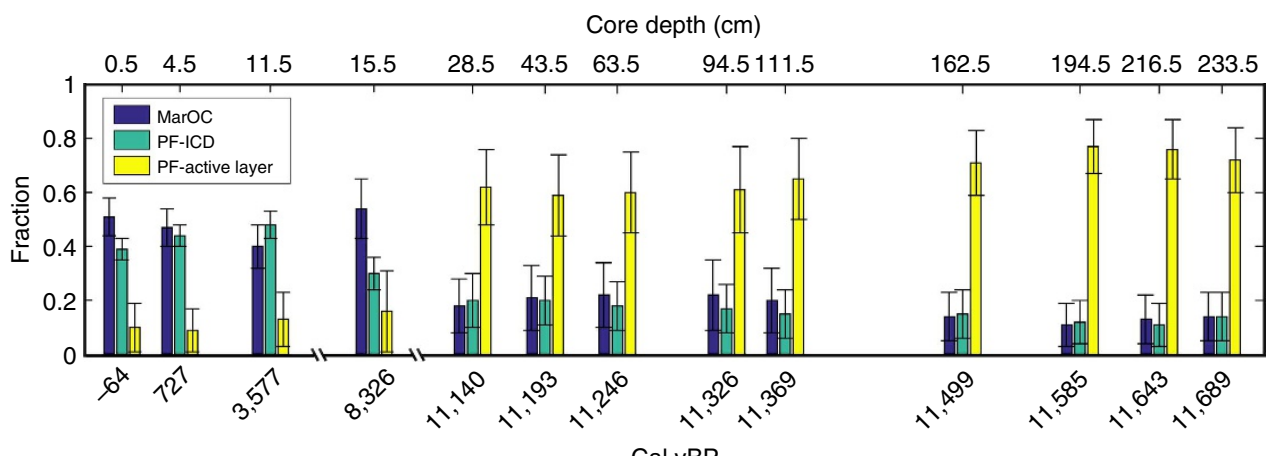

Figure 4 | Varying contribution of three different carbon source classes through the YD-Holocene. Results from source apportionment (Markov Chain Monte Carlo simulations) based on $\delta^{13} \mathrm{C}, \Delta{ }^{14} \mathrm{C}$ and lignin concentration. The source classifications were: Marine OC (MarOC; blue), PF-ICD (teal) and PF-Active-layer (yellow). Upper $x$ axis shows the core depth $(\mathrm{cm})$ and lower $x$ axis shows the age (cal yBP). Bars and whiskers display mean and s.d. of the relative contributions from each source based on the Monte Carlo simulations. 
conditions, sediment transport models show that the mobility of permanently frozen soils is limited ${ }^{46}$. As the temperature increased during the YD-PB transition ${ }^{24}$ (Fig. 6b), the rapid active-layer deepening and the resulting thermokarst development released large quantity of soil carbon ${ }^{47,48}$. In modern Arctic analogues, increased soil erosion as a result of ongoing warming occurs via channelization of previously frozen areas ${ }^{49,50}$, activelayer detachment on hillslopes ${ }^{51}$, gully developments ${ }^{52}$ and retrogressive thaw slump with thawing starting from thermokarst lakes or stream channels ${ }^{53}$ (Fig. 6). It is likely to be that similar processes occurred during past warming events with important implication for the land-to-ocean PF-C fluxes.

On top of this, the termination of the YD corresponds to wetter conditions over the Asian catchments ${ }^{24}$, which have been recorded in the Greenland ice cores as a drop in dust concentration sourced from the Asian deserts 22,33 (Fig. 2d). This probably enhanced the river runoff and, consequently, the supply of recently destabilized PF-C to the Laptev Sea.

It is also possible that this massive washout of active-layer carbon extended spatially to other nearby Arctic watersheds and shelf seas. For instance, there is strong evidence of high sedimentation during the early Holocene in the Chukchi Sea ${ }^{54}$. The upscaling in the eastern regions is presently challenged by the scarce distribution of data, yet the amount of translocated carbon could readily triple if the East Siberia and Chukchi shelves were included in these estimates. Furthermore, these results only cover part of the deglaciation while similar mechanisms may have also occurred during the earlier stage of the deglaciation with the permafrost thawing front progressively moving northwards in the watershed (Fig. 6b).
The evident implication of this massive land-to-ocean OC flux compared with modern river supply is the elevated $\mathrm{CO}_{2}$ outgassing to the atmosphere, which must have occurred both at site of thawing and during long-range transport through the extensive watersheds and coastal regions. This latter scenario is well illustrated today by the continuous oversaturation of $\mathrm{CO}_{2}$ in the Lena River due to the high reactivity of PF- ${ }^{55}$. In aquatic environments, the mineralization is particularly efficient when driven by PF-C leaching. Specifically, recent studies have shown that microbial communities in Arctic rivers are capable of rapidly degrading dissolved $\mathrm{OC}$ on $\mathrm{PF}-\mathrm{C}$ thawing regardless of the age of the carbon ${ }^{56,57}$. After deposition on the seabed, early diagenesis of PF-C further continues as illustrated by bottom waters oversaturated in $\mathrm{CO}_{2}$ over terrestrially dominated Laptev sediments ${ }^{55,58}$.

However, because of the severe deepening of active-layer permafrost, it is likely to be that most of the OC degradation and $\mathrm{CO}_{2}$ venting occurred at the site of thawing and erosion during the post-glacial warming ${ }^{11-13,59}$. Specifically, the presented shelf record of terrestrial carbon deposition reveals elevated sediment production within the watershed, which implies extensive thawing and, consequently, enhanced microbial respiration of previously frozen PF-C $\mathrm{C}^{60,61}$. In modern tundra domains, where active layer deepening has been well documented, old carbon loss ranges between 20 and $80 \mathrm{gC} \mathrm{m}^{-2} \mathrm{y}^{-1}$ (ref. 62). Therefore, given the extent of the Lena watershed and the other rivers adjacent to the Laptev Sea $\left(3.6 \times 10^{7} \mathrm{~km}^{2}\right.$ combined), it is likely to be that post-glacial warming resulted in significant $\mathrm{CO}_{2}$ venting from this vast permafrost domain. In fact, collective evidence based on in-situ and laboratory studies indicates that the extent of $\mathrm{CO}_{2}$

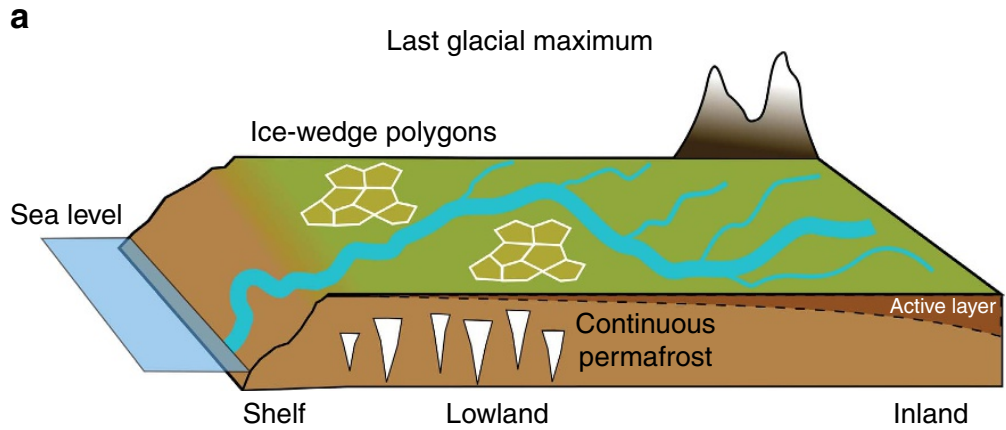

b

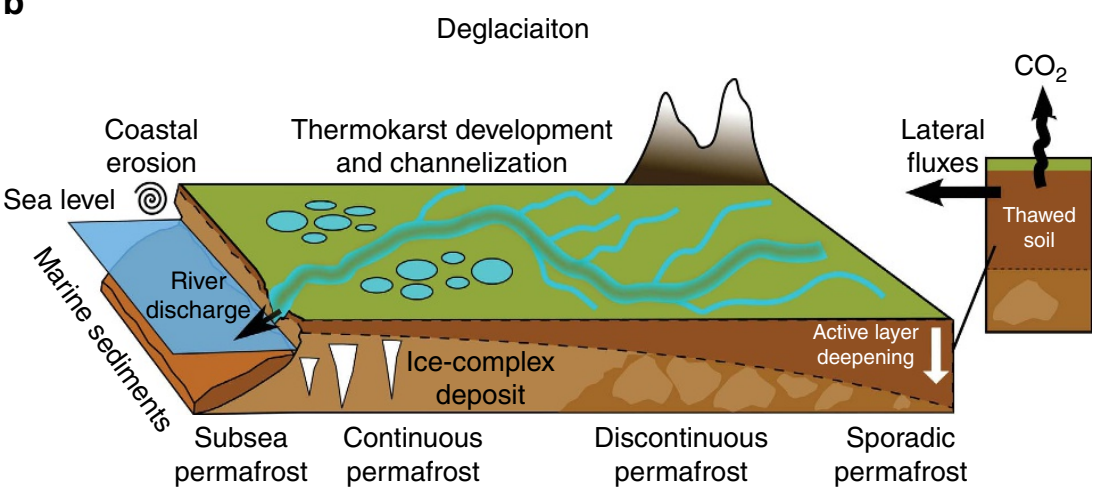

Figure 6 | Illustration showing the land-to-ocean fluxes during glacial and deglacial periods. (a) Glacial conditions (for example, LGM) promote rapid accumulation of permafrost carbon ${ }^{3,4}$ and result in a thin active layer ${ }^{45}$ (dark brown soil colour), while the dominant feature in the watershed is a continuous permafrost (light brown soil colour) with the presence of ice-wedge polygons. Under these conditions, lateral carbon fluxes are small ${ }^{46}$. (b) As the temperature increases during the deglaciation, the permafrost conditions change (development of thermokarst lakes and river channelization), while deepening of the active layer (white arrow) releases material previously locked in frozen soils. This ultimately increases the sediment production (horizontal black arrow), which is illustrated by the darker colour of the river network. The destabilization of permafrost soils probably result in large $\mathrm{CO}_{2}$ venting from freshly thawed PF-C (black vertical arrow). Another source of material includes the coastal erosion (black spiral) as the sea level rises. 
emissions from PF-C soils appears to be largely related to the amount of the unfrozen OC being released via thawing ${ }^{63-65}$.

Regarding the outgassing via anoxic respiration, the $\Delta^{14} \mathrm{C}$ signature of the remobilized active-layer permafrost (after correcting for its age ${ }^{66}$ and the decay until the end of the YD) is relatively more depleted (ca. 400\%) than the age-corrected $\mathrm{CH}_{4}$ radiocarbon values measured in glacial ice during the YD-PB transition $(c a .+150 \% \text { o })^{67}$. This further supports the hypothesis that contemporary sources were likely to be responsible for the majority of the YD-PB $\mathrm{CH}_{4}$ rise $^{67-69}$. However, although a contribution from thawing pre-aged PF-C cannot be excluded $^{70,71}$, more work is clearly needed to understand the fate of PF-C in response to thermokarst development during Last Glacial Termination.

The increase of atmospheric $\mathrm{CO}_{2}$ by $\sim 80$ p.p.m.v. during the deglaciation undoubtedly demonstrates that important reorganization has occurred among Earth system carbon reservoirs ${ }^{6}$. It is still unclear to what extent marine and terrestrial carbon pools have contributed although the emerging picture suggests that a combination of processes must have been operating $2,7,8,10-12$. Our results from Arctic sediments confirm that the last glacialinterglacial transition exerted first-order control on permafrost stability in high latitude watersheds with important consequences for large-scale carbon-climate feedbacks similar to what we might experience as a result of the modern climate change. Given the size of the soil carbon pool held in the northern regions at the $\mathrm{LGM}^{2-4}$, future paleoclimate modelling of global carbon cycling should include the destabilization of northern soils during the deglaciation and understand the climate-induced redistribution of permafrost carbon among atmospheric, oceanic and terrestrial reservoirs.

\section{Methods}

Sediment core collection and handling. The piston core 23 (PC23) was collected in the Laptev Sea (Lat $76^{\circ} 10.26^{\prime} \mathrm{N}$, Long $129^{\circ} 20.22^{\prime} \mathrm{E}$ ) in July 2014 during the SWERUS-C3 expedition (I/B Oden) at $56 \mathrm{~m}$ water depth (Fig. 1 and Supplementary Fig. 1). Split sections were scanned through the ITRAX core scanner (Cox Analytical) to obtain high-resolution X-ray digital images (Supplementary Fig. 2). Step size was set at $340 \mu \mathrm{m}$ with $20 \mathrm{~s}$ exposure time. Post-acquisition image processing was performed with Matlab (Image Toolbox). The downcore submillimetre X-ray brightness (greyscale) was first horizontally averaged and subsequently vertically averaged every centimetre. The $1 \mathrm{~cm}$ resolved brightness was then fitted with the sediment bulk density to obtain an algorithm to convert X-ray brightness into sediment bulk density (Supplementary Fig. 3).

\section{Radiocarbon dating and Bayesian age-depth modelling. For the age-depth} model, a selection of 14 samples was sent to the US-NSF National Ocean Sciences Accelerator Mass Spectrometry facility at Woods Hole Oceanographic Institution (Woods Hole, MA, USA) for radiocarbon dating. Before the submission, samples were rinsed with MilliQ water and sonicated for a few seconds. Radiocarbon ages (yBP) are reported following the international convention (Supplementary Table 1$)^{72,73}$.

The ${ }^{14} \mathrm{C}$ data set of PC23 (Supplementary Table 1) is formed by 11 marine biogenic carbonates covering the uppermost $162 \mathrm{~cm}$ and by three large vascular plant debris constraining the lowermost $89 \mathrm{~cm}$ (Supplementary Fig. 2a). The radiocarbon data set was modelled using OxCal4.2. The marine ${ }^{14} \mathrm{C}$ dates were calibrated using the Marine 13 calibration curve ${ }^{66}$ whereas the terrestrial ${ }^{14} \mathrm{C}$ dates were calibrated using the IntCal13 atmospheric calibration curve ${ }^{66}$. An extra $67 \pm 49$ (based on the database available on http://calib.qub.ac.uk/marine) and $400 \pm 49^{14} \mathrm{C}$-years regional reservoir effect $(\Delta \mathrm{R})$ was added to the top three and the remaining six marine dates, respectively. The larger $\Delta \mathrm{R}\left(400 \pm 49{ }^{14} \mathrm{C}\right.$-years $)$ in the lower region of the core was imposed because of the depleted $\delta^{13} \mathrm{C}$ signature of the biogenic carbonates $(-3.7 \pm 1.5 \%$; Supplementary Fig. $2 b)$ in comparison with the typical signature $(\sim+1 \%)$ in modern high-salinity waters ${ }^{18,44}$. The lower $\delta^{13} \mathrm{C}$ signature is likely to be the result of the freshening during the deglaciation, which implies the supply of a relatively ${ }^{14} \mathrm{C}$-depleted carbon source via rivers ${ }^{44}$.

Bayesian age-depth modelling with $\mathrm{OxCal}$ relies on the correct choice of $k$, a parameter that determines the degree of flexibility of the model on the ${ }^{14} \mathrm{C}$-dating sequence and relates to the nature of the depositional environment ${ }^{74}$. We performed several runs using different $k$ parameters until satisfactory agreement indices ${ }^{75}$ were obtained. The sharp lithological boundary at $23 \mathrm{~cm}$, which marks the interruption in deposition of laminated sediments (based on X-ray images; Supplementary Fig. 3 and core description), was also prescribed in the sequence to define the step change in depositional rates. The Outlier_Model analysis was performed with the General setting and the prior probability fixed to 0.05 , which weighs down the radiocarbon measurement that have statistical probability of $>5 \%$ of being outliers ${ }^{75}$.

The final model was run using a $k$-value of 3 . This value is suitable to constrain ${ }^{14} \mathrm{C}$ data rigidly where little change in sedimentation rate occurred such as for the laminated bottom unit ${ }^{76}$. The output resulted in a robust and coherent age model with an overall solid structure of the dated sequence (Supplementary Fig. 2a) as defined by an excellent agreement index of $94.6 \%$ (ref. 75 ).

Bulk OC analyses. OC and stable carbon isotope $\left(\delta^{13} \mathrm{C}\right)$ analyses were carried out on acidified samples ( $\mathrm{Ag}$ capsules, $\mathrm{HCl}, 1.5 \mathrm{M}$ ) to remove the carbonate fraction ${ }^{77}$. Analyses were performed using a Thermo Electron mass spectrometer directly coupled to a Carlo Erba NC2500 Elemental Analyzer via a Conflo III (Stable Isotope Laboratory (SIL), Department of Geological Sciences, Stockholm University). OC and TN values are reported as weight per cent (\% d.w.; Supplemetary Fig. 4a), whereas stable isotope data are reported in the conventional delta notation (\%; Supplementary Fig. 4a). The analytical error for $\delta^{13} \mathrm{C}$ was lower than $\pm 0.1 \%$ based on triplicate analyses of the same sample.

A subset of 12 bulk sediment samples were acidified $(\mathrm{HCl}, 1.5 \mathrm{M})$ and sent to National Ocean Sciences Accelerator Mass Spectrometry for radiocarbon analyses. Radiocarbon data of bulk OC are reported in the standard $\Delta^{14} \mathrm{C}$ notation $(\%)^{73}$ and as calibrated yBP (Supplementary Table 2).

Biomarkers. The alkaline $\mathrm{CuO}$ oxidation was carried out using an UltraWAVE Milestone microwave ${ }^{78}$. Briefly, $\sim 2 \mathrm{mg}$ of $\mathrm{OC}$ was oxidized using $\mathrm{CuO}$ under alkaline $(2 \mathrm{~N} \mathrm{NaOH})$ and oxygen-free conditions at $150^{\circ} \mathrm{C}$ for $90 \mathrm{~min}$ in teflon tubes. After the oxidation, known amounts of trans-cinnamic acid and ethylvanillin were added to the solution as recovery standards. The aqueous solutions were then acidified to $\mathrm{pH} 1$ with concentrated $\mathrm{HCl}$ and extracted with ethyl acetate. Extracts were dried and redissolved in pyridine. $\mathrm{CuO}$ oxidation products were quantified by gas chromatography-mass spectrometry (GC-MS) in full scan mode $(50-650 \mathrm{~m} / \mathrm{z})$ Before $\mathrm{GC}$ analyses, the $\mathrm{CuO}$ oxidation products were derivatized with bis(trimethylsilyl) trifluoroacetamide $+1 \%$ trimethylchlorosilane at $60^{\circ} \mathrm{C}$ for $30 \mathrm{~min}$. The compounds were separated chromatographically in a $30 \mathrm{~m} \times 250 \mu \mathrm{m}$ DB5 ms $(0.25 \mu \mathrm{m}$-thick film) capillary GC column, using an initial temperature of $100^{\circ} \mathrm{C}$, a temperature ramp of $4^{\circ} \mathrm{C} \mathrm{min}{ }^{-1}$ and a final temperature of $300^{\circ} \mathrm{C}$. Lignin phenols and 3,5-dihydroxybenzoic acid were quantified using the response factors of commercially available standards (Sigma-Aldrich), whereas cutin-derived products were quantified by comparing the response factor of trans-cinnamic acid. Lignin-derived reaction products include vanillyl phenols $(\mathrm{V}=$ vanillin, acetovanillone, vanillic acid), syringyl phenols $(\mathrm{S}=$ syringealdehyde, acetosyringone, syringic acid) and cinnamyl phenols $(\mathrm{C}=p$-coumaric acid, ferulic acid). The quantification of cutin acids focused on the most abundant $\mathrm{C} 16$ to $\mathrm{C} 18$ hydroxy fatty acids: 16-hydroxyhexadecanoic acid, hexadecan-1,16-dioic acid, 18-hydroxyoctadec-9-enoic acid, 7 or 8-dihydroxy C16 $\alpha, \omega$-dioic acid and 8 or 9 or 10,16-dihydroxy C16 acids ${ }^{79,80}$. Quantification of cutin acids was performed using the response factors of trans-cinnamic acid ${ }^{17}$. Results were presented as fluxes (Fig. 2) and OC-normalized data (Supplementary Fig. 4b)

High-molecular weight wax lipids were extracted using an ASE 200 accelerated solvent extractor (Dionex Corporation, USA) using DCM/MeOH $(9: 1 \mathrm{v} / \mathrm{v})$ at $80^{\circ} \mathrm{C}$ $\left(5 \times 10^{6} \mathrm{~Pa}\right)^{81}$. Samples were placed in solvent-rinsed stainless steel vessels. The empty space left in the vessels was filled with pre-combusted and solvent-rinsed glass bits. After the extraction, solvent-rinsed activated copper was added to the extracts to remove sulfur. After $24 \mathrm{~h}$, extracts were filtered on pre-combusted glass wool and concentrated with the rotary evaporator. Extracts were then transferred into test tubes, evaporated to complete dryness and re-dissolved in $500 \mu \mathrm{l}$ of DCM. Extracts were then separated into acid, hydrocarbon and polar fractions using amino-propyl Bond Elut (500 mg per $3 \mathrm{ml}$ ) and column chromatography over $\mathrm{Al}_{2} \mathrm{O}_{3}$. Saturated $n$-alkanes were further isolated using $10 \% \mathrm{AgNO}_{3}$-coated silica gel and quantified by GC-MS in full scan mode $(50-650 \mathrm{~m} / \mathrm{z})$. The GC was equipped with a $30 \mathrm{~m} \times 250 \mu \mathrm{m}$ DB5 $\mathrm{ms}(0.25 \mu \mathrm{m}$ thick film $)$ capillary GC column. Quantification was performed using the response factors of commercially available standards (Sigma-Aldrich). Initial GC oven temperature was set at $60^{\circ} \mathrm{C}$ followed by a $10^{\circ} \mathrm{C} \mathrm{min}^{-1} \mathrm{ramp}$ until a final temperature of $310^{\circ} \mathrm{C}$ (hold time $10 \mathrm{~min}$ ).

Compound-specific isotope analyses. The hydrogen-isotopic abundances of saturated $n$-alkanes were determined in continuous-flow MS. Purified extracts were concentrated and injected $(1-2 \mu \mathrm{l})$ into a Thermo Trace Ultra GC equipped with a $30 \mathrm{~m} \times 250 \mu \mathrm{m}$ HP5 $(0.25 \mu \mathrm{m}$-thick film) capillary GC column. Oven conditions were similar to the setting used for the quantification. The conversion of organic biomarkers to elemental hydrogen was accomplished by pyrolysis at $1,420^{\circ} \mathrm{C}$ (Thermo GC Isolink). After the pyrolysis, $\mathrm{H}_{2}$ was introduced into an isotope ratio mass spectrometer (Thermo Scientific Delta VIRMS) for compound-specific determination of $\delta^{2} \mathrm{H}$ values via a Thermo Conflo IV. Only peaks with amplitude (mass 2) between 1,500 and $8,000 \mathrm{mV}$ were used for the evaluation. The $\delta^{2} \mathrm{H}$ values of the $n$-alkanes were calibrated against the reference substance mix A4 (Biogeochemical Laboratories, Indiana University). The $\mathrm{H} 3+$ factor was determined once a day and stayed constant throughout the evaluation. Each sample 
was injected three times and $\delta^{2} \mathrm{H}$ values are reported as mean, s.d. and weighted average (Supplementary Table 3 and Fig. 6). Only HMW saturated odd $n$-alkanes (C25, C27, C29 and C31) were quantified. Average s.d. for all evaluated peaks was $2.9 \%$ (min $0.3 \%$ and $\max 6.0 \%$; Supplementary Table 3 ).

OC burial and Lena river input. The cumulative OC buried in the transgressive deposit in the Laptev Sea was assessed based on published sediment records available on www.pangea.de ${ }^{18,20,82}$. Location, thickness, average OC content and bulk density are provided in the Supplementary Methods and Supplementary Table 4 along with interpolation methods used for the estimate (OC burial and flux during last phase of the deglaciation/early Holocene).

The modern flux of OC supplied to the Laptev Sea from the Lena River is based on a power law rating curve ${ }^{83,84}$ that was built using data collected by the Arctic Great Rivers Observatory (http://www.arcticgreatrivers.org/data.html). See the Supplementary Methods for further details (comparison with the modern river input).

OC source apportionment. Dual-carbon isotope- and biomarker-based source apportionment calculations were performed using the average composition of representative end-members (that is, ICD, active layer permafrost and marine phytoplankton). The end-member composition relies on data existing in literature (Supplementary Methods, Source apportionment calculations)

To account for the end-member natural variability, we ran a Markov Chain Monte Carlo simulation to estimate the resulting uncertainties in the calculated fractions ${ }^{85}$. Further details about end-member definition and Markov Chain Monte Carlo are provided in the Supplementary Methods (Source apportionment calculations; Supplementary Table 5).

Data availability. All data presented in this study will be publicly available in Stockholm University's Bolin Centre Database (http://bolin.su.se/data/).

\section{References}

1. Hugelius, G. et al. Estimated stocks of circumpolar permafrost carbon with quantified uncertainty ranges and identified data gaps. Biogeosciences 11, 6573-6593 (2014).

2. Ciais, P. et al. Large inert carbon pool in the terrestrial biosphere during the Last Glacial Maximum. Nat. Geosci. 5, 74-79 (2012).

3. Zech, R., Huang, Y., Zech, M., Tarozo, R. \& Zech, W. High carbon sequestration in Siberian permafrost loess-paleosols during glacials. Clim. Past 7, 501-509 (2011).

4. Zimov, N. et al. Carbon storage in permafrost and soils of the mammoth tundra-steppe biome: role in the global carbon budget. Geophys. Res. Lett. 36, L02502 (2009).

5. Marcott, S. A. et al. Centennial-scale changes in the global carbon cycle during the last deglaciation. Nature 514, 616-619 http://www.nature.com/nature/ journal/v514/n7524/abs/nature13799.html\#supplementary-information (2014).

6. Monnin, E. et al. Atmospheric $\mathrm{CO} 2$ concentrations over the last glacial termination. Science 291, 112-114 (2001).

7. Burke, A. \& Robinson, L. F. The Southern Ocean's role in carbon exchange during the last deglaciation. Science 335, 557-561 (2012).

8. Schmitt, J. et al. Carbon isotope constraints on the deglacial $\mathrm{CO} 2$ rise from ice cores. Science 336, 711-714 (2012).

9. Lund, D. C., Mix, A. C. \& Southon, J. Increased ventilation age of the deep northeast Pacific Ocean during the last deglaciation. Nat. Geosci. 4, 771-774 (2011)

10. Ronge, T. A. et al. Radiocarbon constraints on the extent and evolution of the South Pacific glacial carbon pool. Nat. Commun. 7, 11487 (2016).

11. Köhler, P., Knorr, G. \& Bard, E. Permafrost thawing as a possible source of abrupt carbon release at the onset of the Bølling/Allerød. Nat. Commun. 5, $5520(2014)$

12. Crichton, K. A., Bouttes, N., Roche, D. M., Chappellaz, J. \& Krinner, G. Permafrost carbon as a missing link to explain $\mathrm{CO} 2$ changes during the last deglaciation. Nat. Geosci. 9, 683-686 http://www.nature.com/ngeo/journal/v9/ n9/abs/ngeo2793.html\#supplementary-information (2016).

13. Simmons, C. T., Matthews, H. D. \& Mysak, L. A. Deglacial climate, carbon cycle and ocean chemistry changes in response to a terrestrial carbon release. Clim. Dyn. 46, 1287-1299 (2016).

14. Renssen, H. et al. Multiple causes of the Younger Dryas cold period. Nat. Geosci. 8, 946-949 (2015).

15. Muschitiello, F. et al. Timing of the first drainage of the Baltic Ice Lake synchronous with the onset of Greenland Stadial 1. Boreas 45, 322-334 (2016).

16. Muschitiello, F. et al. Fennoscandian freshwater control on Greenland hydroclimate shifts at the onset of the Younger Dryas. Nat. Commun. 6, 8939 (2015).

17. Andersen, K. K. et al. High-resolution record of Northern Hemisphere climate extending into the last interglacial period. Nature 431, 147-151 (2004).
18. Bauch, H. A. et al. Chronology of the Holocene transgression at the North Siberian margin. Glob. Planet. Change 31, 125-139 (2001).

19. Stein, R. \& MacDonald, R. W. The Organic Carbon Cycle in the Arctic Ocean (Springer, 2004).

20. Taldenkova, E., Bauch, H. A., Stepanova, A., Dem'yankov, S. \& Ovsepyan, A. Last postglacial environmental evolution of the Laptev Sea shelf as reflected in molluscan, ostracodal, and foraminiferal faunas. Glob. Planet. Change 48, 223-251 (2005).

21. Stein, R. \& Fahl, K. Holocene accumulation of organic carbon at the Laptev Sea continental margin (Arctic Ocean): sources, pathways, and sinks. Geo-Marine Lett. 20, 27-36 (2000).

22. Binney, H. A. et al. The distribution of late-Quaternary woody taxa in northern Eurasia: evidence from a new macrofossil database. Quat. Sci. Rev. 28, 2445-2464 (2009).

23. Schirrmeister, L. et al. Paleoenvironmental and paleoclimatic records from permafrost deposits in the Arctic region of Northern Siberia. Quat. Int. 89, 97-118 (2002).

24. Tarasov, P., Bezrukova, E. \& Krivonogov, S. Late Glacial and Holocene changes in vegetation cover and climate in southern Siberia derived from a 15 kyr long pollen record from Lake Kotokel. Clim. Past 5, 285-295 (2009).

25. Viscosi-Shirley, C., Pisias, N. \& Mammone, K. Sediment source strength, transport pathways and accumulation patterns on the Siberian-Arctic's Chukchi and Laptev shelves. Continent. Shelf Res. 23, 1201-1225 (2003).

26. Wheatcroft, R. \& Borgeld, J. Oceanic flood deposits on the northern California shelf: large-scale distribution and small-scale physical properties. Continent. Shelf Res. 20, 2163-2190 (2000).

27. Fry, B. \& Sherr, E. B. in Stable Isotopes in Ecological Research 196-229 (Springer, 1989).

28. Winterfeld, M., Laepple, T. \& Mollenhauer, G. Characterization of particulate organic matter in the Lena River delta and adjacent nearshore zone, NE Siberia \&ndash; Part I: radiocarbon inventories. Biogeosciences 12, 3769-3788 (2015).

29. Bianchi, T. S. \& Canuel, E. A. Chemical Biomarkers in Aquatic Ecosystems (Princeton Univ. Press, 2011).

30. Tesi, T. et al. Composition and fate of terrigenous organic matter along the Arctic land-ocean continuum in East Siberia: Insights from biomarkers and carbon isotopes. Geochim. Cosmochim. Acta 133, 235-256 (2014).

31. Bartolomé, M. et al. Hydrological change in Southern Europe responding to increasing North Atlantic overturning during Greenland Stadial 1. Proc. Natl Acad. Sci. USA 112, 6568-6572 (2015).

32. Ruth, U., Wagenbach, D., Steffensen, J. P. \& Bigler, M. Continuous record of microparticle concentration and size distribution in the central Greenland NGRIP ice core during the last glacial period. J. Geophys. Res. Atmos. 108, 4098 (2003).

33. Steffensen, J. P. et al. High-resolution Greenland ice core data show abrupt climate change happens in few years. Science 321, 680-684 (2008).

34. Andersson, A. et al. Regionally-varying combustion sources of the January 2013 severe haze events over Eastern China. Environ. Sci. Technol. 49, 2038-2043 (2015).

35. Grosse, G. et al. Distribution of late Pleistocene ice-rich syngenetic permafrost of the Yedoma Suite in east and central Siberia, Russia. US Geol. Survey Open File Rep. 2013, 1-37 (2013).

36. Günther, F., Overduin, P. P., Sandakov, A. V., Grosse, G. \& Grigoriev, M. N. Short-and long-term thermo-erosion of ice-rich permafrost coasts in the Laptev Sea region. Biogeosciences 10, 4297-4318 (2013).

37. Vonk, J. et al. Activation of old carbon by erosion of coastal and subsea permafrost in Arctic Siberia. Nature 489, 137-140 (2012)

38. Lambeck, K., Rouby, H., Purcell, A., Sun, Y. \& Sambridge, M. Sea level and global ice volumes from the Last Glacial Maximum to the Holocene. Proc. Natl Acad. Sci. USA 111, 15296-15303 (2014).

39. Winterfeld, M., Goñi, M., Just, J., Hefter, J. \& Mollenhauer, G. Characterization of particulate organic matter in the Lena River delta and adjacent nearshore zone, NE Siberia-Part 2: lignin-derived phenol compositions. Biogeosciences 12, 2261-2283 (2015).

40. Yang, H., Liu, W., Leng, Q., Hren, M. T. \& Pagani, M. Variation in n-alkane $\delta D$ values from terrestrial plants at high latitude: implications for paleoclimate reconstruction. Org. Geochem. 42, 283-288 (2011).

41. Feakins, S. J., Warny, S. \& Lee, J.-E. Hydrologic cycling over Antarctica during the middle Miocene warming. Nat. Geosci. 5, 557-560 (2012).

42. Gat, J. R. Oxygen and hydrogen isotopes in the hydrologic cycle. Annu. Rev. Earth Planet Sci. 24, 225-262 (1996).

43. Mueller-Lupp, T. et al. Changes in the deposition of terrestrial organic matter on the Laptev Sea shelf during the Holocene: evidence from stable carbon isotopes. Int. J. Earth Sci. 89, 563-568 (2000).

44. Bauch, H., Erlenkeuser, H., Bauch, D., Müller-Lupp, T. \& Taldenkova, E. Stable oxygen and carbon isotopes in modern benthic foraminifera from the Laptev Sea shelf: implications for reconstructing proglacial and 
profluvial environments in the Arctic. Marine Micropaleontol. 51, 285-300 (2004).

45. Saito, K. et al. LGM permafrost distribution: how well can the latest PMIP multi-model ensembles perform reconstruction? Clim. Past 9, 1697-1714 (2013).

46. Syvitski, J. P. Sediment discharge variability in Arctic rivers: implications for a warmer future. Polar Res. 21, 323-330 (2002).

47. Gooseff, M. N., Balser, A., Bowden, W. B. \& Jones, J. B. Effects of hillslope thermokarst in northern Alaska. Eos Transact. Am. Geophys. Union 90, 29-30 (2009).

48. Rowland, J. C. et al. Arctic landscapes in transition: responses to thawing permafrost. Eos Transact. Am. Geophys. Union 91, 229-230 (2010).

49. Bogaart, P. W., Tucker, G. E. \& De Vries, J. Channel network morphology and sediment dynamics under alternating periglacial and temperate regimes: a numerical simulation study. Geomorphology 54, 257-277 (2003).

50. Toniolo, H., Kodial, P., Hinzman, L. D. \& Yoshikawa, K. Spatio-temporal evolution of a thermokarst in Interior Alaska. Cold Regions Sci. Technol. 56, 39-49 (2009).

51. Lamoureux, S. F., Lafrenière, M. J. \& Favaro, E. A. Erosion dynamics following localized permafrost slope disturbances. Geophys. Res. Lett. 41, 5499-5505 (2014).

52. Osterkamp, T. et al. Physical and ecological changes associated with warming permafrost and thermokarst in interior Alaska. Permafrost Periglacial Process. 20, 235-256 (2009).

53. Mesquita, P. S., Wrona, F. J. \& Prowse, T. D. Effects of retrogressive permafrost thaw slumping on sediment chemistry and submerged macrophytes in Arctic tundra lakes. Freshw. Biol. 55, 2347-2358 (2010).

54. Keigwin, L. D., Donnelly, J. P., Cook, M. S., Driscoll, N. W. \& Brigham-Grette, J. Rapid sea-level rise and Holocene climate in the Chukchi Sea. Geology 34, 861-864 (2006)

55. Semiletov, I. et al. Space-time dynamics of carbon and environmental parameters related to carbon dioxide emissions in the Buor-Khaya Bay and adjacent part of the Laptev Sea. Biogeosciences 10, 5977-5996 (2013).

56. Mann, P. J. et al. Utilization of ancient permafrost carbon in headwaters of Arctic fluvial networks. Nat. Commun. 6, 7856 (2015).

57. Drake, T. W., Wickland, K. P., Spencer, R. G. M., McKnight, D. M. \& Striegl, R. G. Ancient low-molecular-weight organic acids in permafrost fuel rapid carbon dioxide production upon thaw. Proc. Natl Acad. Sci. USA 112, 13946-13951 (2015).

58. Semiletov, I. et al. Acidification of East Siberian Arctic Shelf waters through addition of freshwater and terrestrial carbon. Nat. Geosci. 9, 361-365 http:// www.nature.com/ngeo/journal/v9/n5/abs/ngeo2695.html\#supplementaryinformation (2016).

59. Zeng, N. Glacial-interglacial atmospheric CO2 change - The glacial burial hypothesis. Adv. Atmos. Sci. 20, 677-693 (2003).

60. Hicks Pries, C. E., Schuur, E. A. G., Natali, S. M. \& Crummer, K. G. Old soil carbon losses increase with ecosystem respiration in experimentally thawed tundra. Nat. Clim. Change 6, 214-218 http://www.nature.com/ nclimate/journal/v6/n2/abs/nclimate2830.html\#supplementary-information (2016).

61. Xue, K. et al. Tundra soil carbon is vulnerable to rapid microbial decomposition under climate warming. Nat. Clim. Change 6, 595-600 (2016).

62. Schuur, E. A. et al. The effect of permafrost thaw on old carbon release and net carbon exchange from tundra. Nature 459, 556-559 (2009).

63. Dutta, K., Schuur, E., Neff, J. \& Zimov, S. Potential carbon release from permafrost soils of Northeastern Siberia. Glob. Change Biol. 12, 2336-2351 (2006).

64. Lee, H., Schuur, E. A., Inglett, K. S., Lavoie, M. \& Chanton, J. P. The rate of permafrost carbon release under aerobic and anaerobic conditions and its potential effects on climate. Glob. Change Biol. 18, 515-527 (2012).

65. Karlsson, E. S. et al. Contrasting regimes for organic matter degradation in the East Siberian Sea and the Laptev Sea assessed through microbial incubations and molecular markers. Mar. Chem. 170, 11-22 (2015).

66. Reimer, P. J. et al. IntCal13 and Marine13 radiocarbon age calibration curves 0-50,000 years cal BP. Radiocarbon 55, 1869-1887 (2013).

67. Petrenko, V. V. et al. 14CH4 measurements in Greenland ice: investigating last glacial termination $\mathrm{CH} 4$ sources. Science 324, 506-508 (2009).

68. Brook, E. J., Harder, S., Severinghaus, J., Steig, E. J. \& Sucher, C. M. On the origin and timing of rapid changes in atmospheric methane during the last glacial period. Glob. Biogeochem. Cycles 14, 559-572 (2000).

69. Smith, L. et al. Siberian peatlands a net carbon sink and global methane source since the early Holocene. Science 303, 353-356 (2004).

70. Gaglioti, B. V. et al. Radiocarbon age-offsets in an arctic lake reveal the longterm response of permafrost carbon to climate change. J. Geophys. Res. Biogeosci. 119, 2014JG002688 (2014).
71. Walter, K., Edwards, M., Grosse, G., Zimov, S. \& Chapin, F. Thermokarst lakes as a source of atmospheric $\mathrm{CH} 4$ during the last deglaciation. Science $\mathbf{3 1 8}$, 633-636 (2007).

72. Reimer, P. J., Brown, T. A. \& Reimer, R. W. Discussion: reporting and calibration of post-bomb 14C data. Radiocarbon 46, 1299-1304 (2004)

73. Stuiver, M. \& Polach, H. A. Discussion; reporting of C-14 data. Radiocarbon 19, 355-363 (1977).

74. Ramsey, C. B. Deposition models for chronological records. Quat. Sci. Rev. 27, 42-60 (2008).

75. Ramsey, C. B. Bayesian analysis of radiocarbon dates. Radiocarbon 51, 337-360 (2009).

76. Blockley, S., Ramsey, C. B., Lane, C. \& Lotter, A. Improved age modelling approaches as exemplified by the revised chronology for the Central European varved lake Soppensee. Quat. Sci. Rev. 27, 61-71 (2008).

77. Nieuwenhuize, J., Maas, Y. E. \& Middelburg, J. J. Rapid analysis of organic carbon and nitrogen in particulate materials. Mar. Chem. 45, 217-224 (1994).

78. Goñi, M. A. \& Montgomery, S. Alkaline $\mathrm{CuO}$ oxidation with a microwave digestion system: Lignin analyses of geochemical samples. Anal. Chem. 72, 3116-3121 (2000).

79. Goñi, M. A. \& Hedges, J. I. Cutin-derived cuo reaction-products from purified cuticles and tree leaves. Geochim. Cosmochim. Acta 54, 3065-3072 (1990).

80. Hedges, J. I. \& Mann, D. C. Characterization of plant-tissues by their lignin oxidation-products. Geochim. Cosmochim. Acta 43, 1803-1807 (1979).

81. Wiesenberg, G., Schwark, L. \& Schmidt, M. Improved automated extraction and separation procedure for soil lipid analyses. Eur. J. Soil Sci. 55, 349-356 (2004).

82. Fahl, K. \& Stein, R. Biomarkers as organic-carbon-source and environmental indicators in the Late Quaternary Arctic Ocean: problems and perspectives. Mar. Chem. 63, 293-309 (1999).

83. Hatten, J. A., Goñi, M. A. \& Wheatcroft, R. A. Chemical characteristics of particulate organic matter from a small, mountainous river system in the Oregon Coast Range, USA. Biogeochemistry 107, 43-66 (2012).

84. Hilton, R. G., Galy, A., Hovius, N., Horng, M.-J. \& Chen, H. Efficient transport of fossil organic carbon to the ocean by steep mountain rivers: an orogenic carbon sequestration mechanism. Geology 39, 71-74 (2011)

85. Bosch, C. et al. Source apportionment of polycyclic aromatic hydrocarbons in central european soils with compound-specific triple isotopes $(\delta 13 \mathrm{C}, \Delta 14 \mathrm{C}$, and ¿2H). Environ. Sci. Technol. 49, 7657-7665 (2015).

86. Brown, J., Ferrians, Jr O., Heginbottom, J. \& Melnikov, E. Circum-Arctic Map of Permafrost and Ground-Ice Conditions, Version 2 (National Snow And Ice Data Center Boulder, Colorado, USA, 2002).

87. Rasmussen, S. O. et al. A new Greenland ice core chronology for the last glacial termination. J. Geophys. Res. Atmos. 111, D06102 (2006).

\section{Acknowledgements}

We thank the Oden Swedish icebreaker crew and the Swedish Polar Research Secretariat staff. We also acknowledge Dr Henry Holmstrand (Delta Facility, Stockholm University) who provided support for compound specific analyses and Kirsi Keskitalo who helped in the lab. This study was supported by the Knut and Alice Wallenberg Foundation (KAW contract 2011.0027), the Swedish Research Council (VR contract 621-2004-4039 and 621-2007-4631) and the Nordic Council of Ministers Cryosphere-Climate-Carbon Initiative (project Defrost, contract 23001). T.T. additionally acknowledges EU financial support as Marie Curie fellow (contract number PIEF-GA-2011-300259). I.S. acknowledges financial support from the Russian Government (grant number 14, Z50.31.0012/03.19.2014) and the Russian Foundation for Basic Research (numbers 13-05-12028 and 13-05-12041), and O.D. from the Russian Scientific Foundation (grant number 15-17-20032). This is ISMAR-BO contribution number 1902. We thank three anonymous reviewers for their constructive comments. Ö.G. acknowledges the European Research Council (ERCAdG project CC-TOP \#695331).

\section{Author contributions}

T.T. and Ö.G. planned the sampling activity. J.E.V. and P.H. provided support in the field together with the Swedish Polar Research Secretariat and the Oden I/B crew. M.J., N.K. and R.N. took care of seismic data acquisition and post-processing. F.M. developed the age-depth model of PC23. T.T. carried out all analytical analyses on PC23. A.A. ran the MCMC simulation for the OC source apportionment. T.T. wrote the paper with input from all co-authors and produced the figures.

\section{Additional information}

Supplementary Information accompanies this paper at http://www.nature.com/ naturecommunications 
Competing financial interests: The authors declare no competing financial interests.

Reprints and permission information is available online at http://npg.nature.com/ reprintsandpermissions/

How to cite this article: Tesi, T. et al. Massive remobilization of permafrost carbon during post-glacial warming. Nat. Commun. 7, 13653 doi: 10.1038/ncomms13653 (2016).

Publisher's note: Springer Nature remains neutral with regard to jurisdictional claims in published maps and institutional affiliations. (c) (i) This work is licensed under a Creative Commons Attribution 4.0 International License. The images or other third party material in this article are included in the article's Creative Commons license, unless indicated otherwise in the credit line; if the material is not included under the Creative Commons license, users will need to obtain permission from the license holder to reproduce the material. To view a copy of this license, visit http://creativecommons.org/licenses/by/4.0/

(C) The Author(s) 2016 